\title{
Trophic diversity of idoteids (Crustacea, Isopoda) inhabiting the Posidonia oceanica litter
}

\author{
Nicolas Sturaro ${ }^{1}$, Stéphane Caut ${ }^{1,2}$, Sylvie Gobert ${ }^{1}$, Jean-Marie Bouquegneau ${ }^{1}$, Gilles Lepoint ${ }^{1}$ \\ ${ }^{1}$ MARE Centre, Laboratoire d'Océanologie, Université de Liège, Sart Tilman B6, 4000 Liège, Belgium \\ ${ }^{2}$ Estación Biológica de Doñana, Consejo Superior de Investigationes Científicas (CSIC), Apdo. 1056, 41080 Sevilla, Spain
}

\begin{abstract}
The coexistence of three idoteid species in Posidonia oceanica litter raises the question of trophic diversity and their role in the litter degradation process. Hence, diet composition of Idotea balthica, Idotea hectica and Cleantis prismatica was studied using a combination of gut contents and stable isotopes analysis. Gut content observations indicate that $P$. oceanica dead leaves are an important part of the ingested food for the three species, although their tissues are constituted of only a small to medium fraction of $P$. oceanica carbon. Our results also underlined the potential role of these species in the degradation of $P$. oceanica litter by mechanically fragmenting the litter and by assimilating a small to medium fraction of carbon. Moreover, we showed that there were considerable inter- and intra-specific differences in diet composition. Diet differed between juveniles and adults for I. balthica. Crustaceans are an important food source for adults of I. balthica, while I. hectica indicated a major contribution of algal material. $C$. prismatica showed an intermediate diet. This trophic diversity is probably one of the factors allowing these species to coexist in the same biotope.
\end{abstract}

\section{Introduction}

In the Mediterranean Sea, Posidonia oceanica (L.) Delile is the most common seagrass and is an important primary producer in coastal areas. Herbivory on this particular species accounts for $2-57 \%$ of the annual leaf production (Cebrián et al. 1996; Havelange et al. 1997; Prado et al. 2007). The remaining fraction of primary production passes into the detritus food web (Wittmann et al. 1981; Mateo and Romero 1997; Pergent et al. 1994). In September and October, P. oceanica leaves fall and contribute to the formation of a leaf litter that remains within the meadow, frequently in sand patches, or are exported to other ecosystems (e.g., upper littoral, sand ecosystems and even deep coastal waters) where it may represent a trophic input of considerable importance (Fenchel 1977). Such leaf litter, often mixed with $P$. oceanica rhizomes and drift macroalgae from adjacent habitats, forms dense packs and may persist for a few days only or for several months or even years, depending on its degree of exposure to hydrodynamic movements and biological phenomena (e.g., bacterial degradation and activity of the detritivorous macrofauna; Wittmann et al. 1981).

Posidonia oceanica litter provides a structural habitat as well as potential food sources for an abundant animal community (Gallmetzer et al. 2005). Crustaceans (mainly amphipods and isopods) are the dominant component of the macrofauna, playing a significant role in the litter degradation process of seagrass systems (Fenchel 1970; Wittmann et al. 1981). Seagrass leaf litter is often an important constituent of material ingested by animals, but the question of assimilation rates of this material for various macroinvertebrates is still being debated (Mateo et al. 2006). Other food sources present in the same biotope, such as epiphytic algae or drift algae are perhaps more readily utilized by consumers than higher plants. Algae are richer in nutrients such as nitrogen, while Posidonia leaves are characterized by a high lignocellulose content (Buia et al. 2000; Klap et al. 2000), which does not allow easy digestion. $P$. oceanica litter is also colonized by microorganisms (diatoms, bacteria and fungi) that could constitute a potential food source for the detritivore communities (Mazzella et al. 1992; Lepoint et al. 2006).

The importance of the different sources in the diet of a consumer can be approached by the examination of gut contents. Nevertheless, this current method cannot provide any information on the assimilated materials. One method that allows measurement of assimilated materials is stable isotope analysis. Indeed, the isotopic composition of an animal is the weighted mixing of the isotopic composition of its food source(s) (after accounting for isotopic fractionation) (DeNiro and Epstein 1981). The stable isotope approach has already been 
used to study the trophic regimes of consumers in P. oceanica ecosystem (Dauby 1989, 1995; Jennings et al. 1997; Lepoint et al. 2000; Vizzini et al. 2002) and in litter accumulations (Lepoint et al. 2006).

The diet of marine detritivore species has been infrequently studied. In the Mediterranean Sea, the idoteids Idotea balthica basteri (Audouin, 1827) and Idotea hectica (Pallas, 1772) and the idoteid-like Cleantis prismatica (Risso, 1826) are commonly found in $P$. oceanica litter. I. balthica and $C$. prismatica primarily inhabit $P$. oceanica litter (Gallmetzer et al. 2005; Dimech et al. 2006), whereas I. hectica is classically described as characteristic of the foliar stratum of the $P$. oceanica bed (Lorenti and Fresi 1983a). In terms of abundance, $I$. balthica can account for $9-14 \%$ of the total litter macrofauna, with mean density exceeding 520 individuals per $\mathrm{m}^{2}$ (Cox 2004; Dimech et al. 2006). Other two idoteids reach in general a mean of 75 individuals per $\mathrm{m}^{2}$ for $I$. hectica (Dimech et al. 2006) and between 3 and 5 individuals per kilogram dry weight of $P$. oceanica litter for $C$. prismatica (Gallmetzer et al. 2005). To make coexistence possible and reduce competition, co-occurring detritivores usually differ in terms of feeding apparatus morphology, feeding strategies, nutritional requirements or digestive capabilities (Arsuffi and Suberkropp 1989; Graça et al. 1993; Zimmer et al. 2002; Zimmer and Bartholmé 2003). Hence, the coexistence of these species in the same biotope raised the question about trophic diversity in this particular environment. To our knowledge, no data are available about the feeding ecology of $I$. hectica and $C$. prismatica, while I. balthica food includes both vegetable (plant and algae) and animal materials (Naylor 1955; Nicotri 1980; Jormalainen et al. 2001). Laboratory observations suggested that I. balthica actively consume living and decaying $P$. oceanica material (Lorenti and Fresi 1983b). This latter is generally considered, together with the sparid fish Sarpa salpa and the echinoid Paracentrotus lividus, as a potential consumer of $P$. oceanica leaves. However, the literature does not provide any complete information about the ability of these isopod species to assimilate this matter.

This study combined gut content and stable isotope analyses to (1) examine inter- and intra-specific differences in diet composition of these three shallow-water idoteid isopods associated to $P$. oceanica litter; (2) evaluate the importance of $P$. oceanica litter in their diet in order to better elucidate the transfer of organic matter from primary producers to detritivores and (3) clarify the potential role of these species in the ecosystem through the consumption and assimilation of $P$. oceanica litter.

\section{Materials and methods}

\section{Study area}

The study was carried out in the Revellata Bay (Gulf of Calvi, Western Corsica, France) (8 43' 44"E; 42 33' $\left.48^{\prime \prime N}\right)$ near the oceanographic station STARESO, on a large central sand patch ( 2.6 ha) surrounded by $P$. oceanica seagrass beds and rocky shore biota (Fig. 1). The seagrass $P$. oceanica covers $40 \%$ of the bay sea bottom, reaching a depth of $40 \mathrm{~m}$ (Janssens 2000), and annual leaf primary production was estimated to be $849 \mathrm{~g}$ dry wt $\mathrm{m}^{-2}$ at $2 \mathrm{~m}$ depth (Vela 2006). The main epilithic macroalgae are Halopteris spp. and Dictyota spp. and, to a lesser extent, Cystoseira spp., Udotea petiola, Sphaerococcus sp. and some erect corallines, growing on adjacent rocks or as epiphytes of $P$. oceanica rhizomes. Some of these species appear in litter accumulations as drift macroalgae. The studied sand patch is an accumulation zone for the litter, defined in this study as fragmented $P$. oceanica leaf material, sometimes mixed with intact leaves, drift macroalgae, living and dead $P$. oceanica roots and rhizomes, which forms aggregates of $\sim 10 \mathrm{~m}$.

\section{Sample collection}

Samples of $P$. oceanica litter were collected during the daytime by SCUBA diving between 4 and $6 \mathrm{~m}$ depth in March 2004 and 2005. SCUBA divers placed the leaf litter material, together with the associated macrophytes debris and macrofauna, inside 30-1 plastic bags and closed them to limit fauna escape. According to a simple random sampling, seven replicate samples were taken in the study area from the top layer of different litter accumulation zones, each separated by 1-10 m. Macrofaunal species were carefully sorted, and specimens of Idotea balthica basteri, Idotea hectica sensu Charfi-Cheikhrouha (2000) and Cleantis prismatica sensu Poore and Lew Ton (1990) (junior synonym Zenobiana prismatica) were caught and transferred to the freezer at $-18^{\circ} \mathrm{C}$ within a few hours, until further analysis. Before dissection, the sex, body length (anterior border of the cephalon to the end of the telson) $( \pm 0.1 \mathrm{~mm})$, body colour (brown or green) and colour morph (i.e., melanophore pattern) of each individual was determined (classification according to Tinturier-Hamelin 1963; Salemaa 1978). The different potential food sources used for isotopic analysis were collected in the study area: P. oceanica dead leaves (i.e., senesced leaves from $P$. oceanica, detached and exported to litter accumulations), $P$. oceanica leaf epiphytes (both algae and fixed animals) that were separated from $P$. oceanica dead leaves in the laboratory by scraping them off with a razor blade, drift macroalgae species found in litter (six species of sciaphilous algae and 
eight species of photophilous algae) and crustaceans (the amphipod Gammarus aequicauda, the most abundant species in the study area, representing $>70 \%$ of litter fauna; Cox 2004).

Fig. 1 Location of the sampling site and distribution of the different benthic ecosystems in Revellata Bay according to Pasqualini (1997) (Gulf of Calvi, NW Corsica)

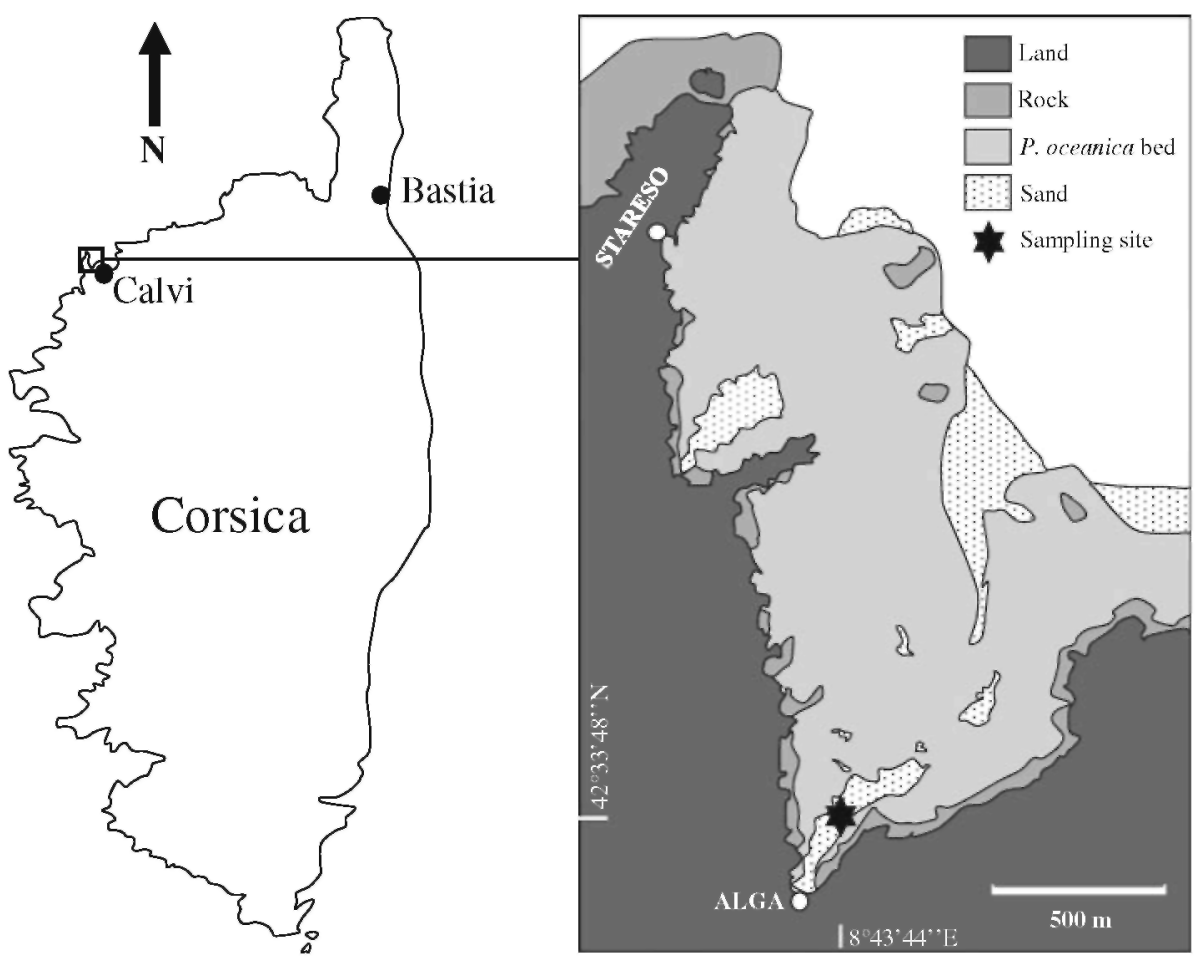

\section{Gut content analysis}

Specimens were dissected under stereoscopic microscope, and the digestive tract was extracted and observed under optic microscope. The gut content analysis allowed the food sources to be separated into six components: $P$. oceanica dead leaves, crustaceans, algae (diatoms, macroalgae and $P$. oceanica vegetal epiphytes), animal epiphytes (foraminifera, bryozoans and sponges), $P$. oceanica living leaves and non-identified organic matter for each individual. Two indices were used for diet description and analysis: frequency of occurrence $(\mathrm{Fi})$ (percentage of all non-empty guts in which the component $\mathrm{i}$ was found) and abundance level (Ai). For this latter, components were itemized and described with three levels of abundance: (1) absent (-): the component i was not present in the gut tract; (2) rare (+): the component i was identified 1-4 times in the gut tract and (3) abundant $(++)$ : five items or more of the component $\mathrm{i}$ were identified, often in different regions of the gut tract.

\section{Stable isotope analysis}

Specimens and potential food sources were dried for $48 \mathrm{~h}$ at $50^{\circ} \mathrm{C}$ and ground into a homogeneous fine powder. When the individual specimen size was equal to or greater than $10 \mathrm{~mm}$, it was possible to perform individual isotopic analysis. Other individuals were pooled according to the following size classes: 2 for I. balthica: $<5$ and 5-10 $\mathrm{mm}$ and 2 for $C$. prismatica: 5-9 and 9-10 $\mathrm{mm}$. To remove carbonates, which are known to be more enriched in $\mathrm{C}$ than dietary organic components, the samples were acidified with $1 \mathrm{~N} \mathrm{HCl}$ for $24 \mathrm{~h}$ and then rinsed with deionized water and oven dried at $50^{\circ} \mathrm{C}$ for $48 \mathrm{~h}$. Stable carbon and nitrogen isotope analysis was performed with a mass spectrometer (Optima, Micromass, UK) coupled to a C-N-S elemental analyzer (Carlo Erba, Italy). All ${ }^{15} \mathrm{~N} /{ }^{14} \mathrm{~N}$ ratios were measured before acidification because of the modifications of ${ }^{15} \mathrm{~N} /{ }^{14} \mathrm{~N}$ after $\mathrm{HCl}$ addition (Bunn et al. 1995). The isotopic analysis was reported in $\delta$ values in parts per thousand (\%o) relative to the Vienna Pee Dee belemnite (vPDB) for carbon samples and atmospheric $\mathrm{N}_{2}$ for nitrogen: 


$$
\begin{gathered}
\delta^{13} \mathrm{C} \text { or } \delta^{15} \mathrm{~N}=\left(\frac{R_{\text {sample }}-R_{\text {standard }}}{R_{\text {standard }}}\right) \times 10^{3} \\
\text { where } R=\frac{{ }^{13} \mathrm{C}}{{ }^{12} \mathrm{C}} \text { or } \frac{{ }^{15} \mathrm{~N}}{{ }^{14} \mathrm{~N}}
\end{gathered}
$$

Reference materials from IAEA were IAEA-N2 (ammonium sulphate) $(20.3 \pm 0.2 \%$ ) and IAEA CH-6 (sucrose) $(-10.4 \pm 0.2 \%$ ). Hundreds of replicate assays of internal laboratory standards (powder of glycine) indicate measurement errors (SD) of \pm 0.3 and $\pm 0.3 \%$ o for stable carbon and nitrogen isotope measurements, respectively.

Jackson et al. (2009) developed a package called SIAR for solving linear-mixing models. This model uses Bayesian inference to solve for the most likely set of dietary proportions given the isotopic ratios in a set of possible food sources and a set of consumers. The model assumes that each target value comes from a Gaussian distribution with an unknown mean and standard deviation. The structure of the mean is a weighted combination of the food sources' isotopic values. The weights are made up of dietary proportions (which are given a Dirichlet prior distribution), and the concentration dependencies given for the different food sources. The standard deviation is divided up between the uncertainty around the discrimination corrections and the natural variability between target individuals (Jackson et al. 2009; Moore and Semmens 2008).

Animal metabolism generally leads to an increase in ${ }^{15} \mathrm{~N}$ abundance in animal tissue compared to its diet (i.e., isotopic fractionation). To account for this fractionation, we subtracted $0.5 \%$ o from the nitrogen isotope signature of each sample as estimated for detritivorous crustaceans by Vanderklift and Ponsard (2003). No adjustment was made for carbon, because $\delta^{13} \mathrm{C}$ fractionation is close to zero (Peterson and Fry 1987).

\section{Statistics}

Statistical analysis was performed using STATISTICA software (version 8.0, StatSoft Inc. 2007). Because data did not fit assumptions of normality, a non-parametric Kruskal-Wallis $H$-test was used for comparisons of isotope ratios between the different food sources and the different isopod species. Subsequently, significant differences were localized by using Mann-Whitney $U$-tests, which also allowed a comparison of differences among sexes and colour morphs. Regression analysis was carried out to examine the relationship between body length and stable isotope values $\left(\delta^{13} \mathrm{C}\right.$ and $\left.\delta^{15} \mathrm{~N}\right)$ of $I$. balthica. No regression analysis was carried out for $I$. hectica and $C$. prismatica because of the limited range of body lengths.

\section{Results}

A total of 70 individuals were sampled: I. balthica ( $n=45: 5$ males, 25 females and 15 juveniles), I. hectica $(n=$ 15: 10 males and 5 females) and $C$. prismatica ( $n=10: 3$ males and 7 females). Isopod species showed little variation in size except in I. balthica, where individuals measuring less than $7 \mathrm{~mm}$ were classified as juveniles (Salemaa 1979; Guarino et al. 1993). I. balthica ranged from 2.6 to $25.9 \mathrm{~mm}$ (avg. 4.1 and $11.2 \mathrm{~mm}$ for juveniles and adults, respectively), I. hectica from 10.7 to $21.9 \mathrm{~mm}$ (avg. $14.8 \mathrm{~mm}$ ) and C. prismatica from 5.5 to $10.4 \mathrm{~mm}$ (avg. $8.4 \mathrm{~mm}$ ). All individuals were brown except in I. hectica where two specimens were green. Six colour morphs were identified for I. balthica specimens: uniformis, bilineata, maculata, pseudolineatai bilineatalineata and albafusca-bilineata. The morph uniformis largely dominates among sampled individuals (81\%).

\section{Gut contents}

From a total of 45 I. balthica guts analyzed, four were empty. Gut contents of adult $I$. balthica were dominated by $P$. oceanica dead leaves ( $88 \%$ of occurrence), crustaceans $(46 \%)$ and non-identified organic matter $(100 \%)$. Animal epiphytes and $P$. oceanica living leaves occurred, respectively, in 17 and $10 \%$ of gut contents and were rare in terms of abundance (Table 1).

Of the 15 I. hectica guts analyzed, four were empty. Gut contents of I. hectica were dominated by P. oceanica dead leaves, algae and non-identified organic matter ( $>90 \%$ of occurrence for these last food sources). Gut contents of this species also include large amounts of $P$. oceanica living leaves (25\% of occurrence) and rare amounts of crustaceans (33\%) and animal epiphytes (45\%).

From the $10 C$. prismatica guts analyzed, seven were empty. $C$. prismatica had gut contents dominated by $P$. oceanica dead leaves and non-identified organic matter (100\% of occurrence). Crustaceans (33\%), algae (100\%) and animal epiphytes $(33 \%)$ were rare. 
Generally, $P$. oceanica dead leaves and non-identified organic matter dominated the gut contents of the three species. Crustaceans were more abundant in I. balthica than in I. hectica and C. prismatica, while algae and $P$. oceanica living leaves were more abundant in I. hectica than in I. balthica and C. prismatica gut contents. Hence, according to gut content analysis, four potential food sources were distinguished for isotopic analysis: $P$. oceanica dead leaves, crustaceans of the litter, drift sciaphilous algae and a mixed food source composed of drift photophilous algae and P. oceanica leaf epiphytes.

Table 1 Gut content analysis (GCA) on individuals with full guts of Idotea balthica $(n=41)$, Idotea hectica $(n=$ 11) and Cleantis prismatica $(n=3)$

\begin{tabular}{lllllll}
\hline Food sources & \multicolumn{2}{l}{ Idotea balthica } & \multicolumn{2}{l}{ Idotea hectica } & \multicolumn{2}{c}{ Cleantis prismatica } \\
\cline { 2 - 7 } & $F(\%)$ & $A$ & $F(\%)$ & $A$ & $F(\%)$ & $A$ \\
\hline P. oceanica dead leaves & 88 & ++ & 92 & ++ & 100 & ++ \\
Crustaceans & 46 & ++ & 33 & + & 33 & + \\
Algae & 29 & ++ & 92 & ++ & 100 & + \\
Animal epiphytes & 17 & + & 45 & + & 33 & + \\
$P$. oceanica living leaves & 10 & + & 25 & ++ & 0 & - \\
Non-identified organic & 100 & ++ & 100 & ++ & 100 & ++ \\
matter & & & & & & \\
\hline
\end{tabular}

$F(\%)$ frequency of occurrence and $A$ abundance of fragments of each food source (-: absent, $+:<5,++: \geq 5)$

\section{Stable isotope values}

Drift macroalgae were separated into two ecological groups (sciaphilous and photophilous algae), with drift sciaphilous algae lower in $\delta^{13} \mathrm{C}(-29.7 \pm 4.5 \%$ o $)$ than drift photophilous algae $(-19.8 \pm 2.3 \%$ ) . Drift photophilous algae and $P$. oceanica leaf epiphytes had very similar $\delta^{13} \mathrm{C}$ and were aggregated into one potential food source ($20.1 \pm 2.6 \%$ o) , because it was not possible to differentiate between them with isotopic models (Caut et al. 2008; Table 2; Fig. 2). P. oceanica dead leaves and crustaceans of the litter had significantly more enriched $\delta^{13} \mathrm{C}$ values than other potential food sources, with $P$. oceanica dead leaves higher in $\delta^{13} \mathrm{C}(-13.3 \pm 0.8 \%)$ than crustaceans $(-$ $16.4 \pm 0.8 \%$ o). The $\delta^{15} \mathrm{~N}$ values of the four potential food sources ranged from 1.3 to $3.0 \%$. Stable isotope values of the four potential food sources were generally well separated using both carbon and nitrogen.

The $\delta^{13} \mathrm{C}$ values of the isopod species ranged from $-23.4 \%$ to $-18.6 \%$ (Table 2; Fig. 2). I. balthica and $C$. prismatica (-19.3 $\pm 0.5 \%$ and $-20.0 \pm 0.9 \%$, respectively) had higher $\delta^{13} \mathrm{C}$ values than I. hectica $(-22.3 \pm 0.8 \%$ o $(P=0.0001)$. The three species had very similar $\delta^{15} \mathrm{~N}$ values for adult specimens: I. balthica $(3.0 \pm 0.7 \%$ o $), I$. hectica $(2.6 \pm 0.5 \% o)$ and $C$. prismatica $(2.7 \pm 0.3 \%$ o , and there were no significant differences among them $(P=$ 0.236). For all specimens of $I$. balthica (all size categories), $\delta^{15} \mathrm{~N}$ values ranged from 1.6 to $4.1 \% \circ$ (Fig. 2). There was a significant correlation between body length and $\delta^{15} \mathrm{~N}$ values for I. balthica $\left(r^{2}=0.36, P=0.003\right.$; Fig. 3), while no significant relationship was observed between body length and $\delta^{13} \mathrm{C}$ values $(P=0.815)$. Further, we did not detect any differences between delta values of the uniformis and the other five colour morphs for I. balthica $(P>0.300)$ and between delta values of males and females for I. balthica and I. hectica $(P>0.270)$.

\section{Food source contributions}

The ranges of feasible contributions for each food source to the three species are shown in Fig. 4. For I. balthica, the model suggested that crustaceans appeared to constitute the majority of the diet with a mean of $31 \%$. Drift sciaphilous algae and drift photophilous algae and epiphytes were both potentially significant contributors to the diet of I. balthica (mean of 23 and $26 \%$, respectively). The latter two food sources were likely to be major contributors to the diet of $I$. hectica (40 and 32\%, respectively), while crustaceans had a smaller dietary contribution (mean of $10 \%$ ). For the last consumer $C$. prismatica, drift photophilous algae and epiphytes was a potentially significant contributor $(27 \%)$, but the range of potential contribution was wide. The contribution of crustaceans to the food source was also relatively important $(20 \%)$, while the other potential food sources made up the remainder of the diet. $P$. oceanica dead leaves accounted for a medium dietary contribution to all three species (20, 18 and $25 \%$ for I. balthica, I. hectica and C. prismatica, respectively). 
Table 2 Mean values (SD) oi $\delta^{13} C, \delta^{15} N, \% C$ and $\% N$ for potential food sources and consumers with different size categories

\begin{tabular}{llllll}
\hline & $n$ & $\delta^{13} \mathrm{C}$ & $\delta^{15} \mathrm{~N}$ & $\% \mathrm{C}$ & $\% \mathrm{~N}$ \\
\hline Potential food sources & & & & & \\
$P$. oceanica dead leaves & 20 & $-13.3(0.8)$ & $1.3(0.6)$ & $27.4(1.4)$ & $0.5(0.1)$ \\
Crustaceans & 30 & $-16.4(0.8)$ & $3.0(0.6)$ & $48.7(0.9)$ & $7.8(1.1)$ \\
Drift sciaphilous algae & 6 & $-29.7(4.5)$ & $1.8(0.7)$ & $28.0(2.9)$ & $2.9(0.4)$ \\
Drift photophilous algae & 8 & $-19.8(2.3)$ & $1.9(0.9)$ & $25.2(2.6)$ & $1.3(0.1)$ \\
P. oceanica leaf epiphytes & 9 & $-20.3(0.6)$ & $1.9(0.5)$ & $38.7(4.0)$ & $1.4(0.4)$ \\
Consumers & & & & \\
Idotea balthica & & $-19.3(0.5)$ & $2.9(0.7)$ & $47.8(2.8)$ & $7.9(1.0)$ \\
$\quad<5$ (mm)* & 10 & -19.2 & 1.6 & & \\
5-10 (mm)* & 27 & -19.2 & 2.2 & & \\
$>10(\mathrm{~mm})$ & 20 & $-19.3(0.5)$ & $3.0(0.7)$ & & \\
Idotea hectica & & $-22.3(0.8)$ & $2.6(0.5)$ & $47.8(1.4)$ & \\
10-12(mm)* & 5 & -22.5 & 2.1 & & \\
$>12(\mathrm{~mm})$ & 7 & $-22.3(0.9)$ & $2.6(0.6)$ & & \\
Cleantis prismatica & & $-20.0(0.9)$ & $2.7(0.3)$ & $48.9(1.1)$ & \\
5-9 (mm)* & 7 & -19.1 & 2.3 & & \\
9-10 (mm)* & 2 & -20.9 & 2.7 & & \\
$>10(\mathrm{~mm})$ & 1 & -20.0 & 3.0 & & \\
\hline
\end{tabular}

$n$ for potential food sources: number of samples and $n$ for consumers: number of individual specimens

* Pooled specimens

Fig. $2 \delta^{13} C$ and $\delta^{15} N$ signatures of Idotea balthica, Idotea hectica and Cleantis prismatica (black and white colours indicate isotope values for individual and pooled specimens, respectively) and of their potential food sources (mean \pm SD). DSA drift sciaphilous algae, DPAE drift photophilous algae and epiphytes of Posidonia oceanica, CR crustaceans and PDL Posidonia oceanica dead leaves

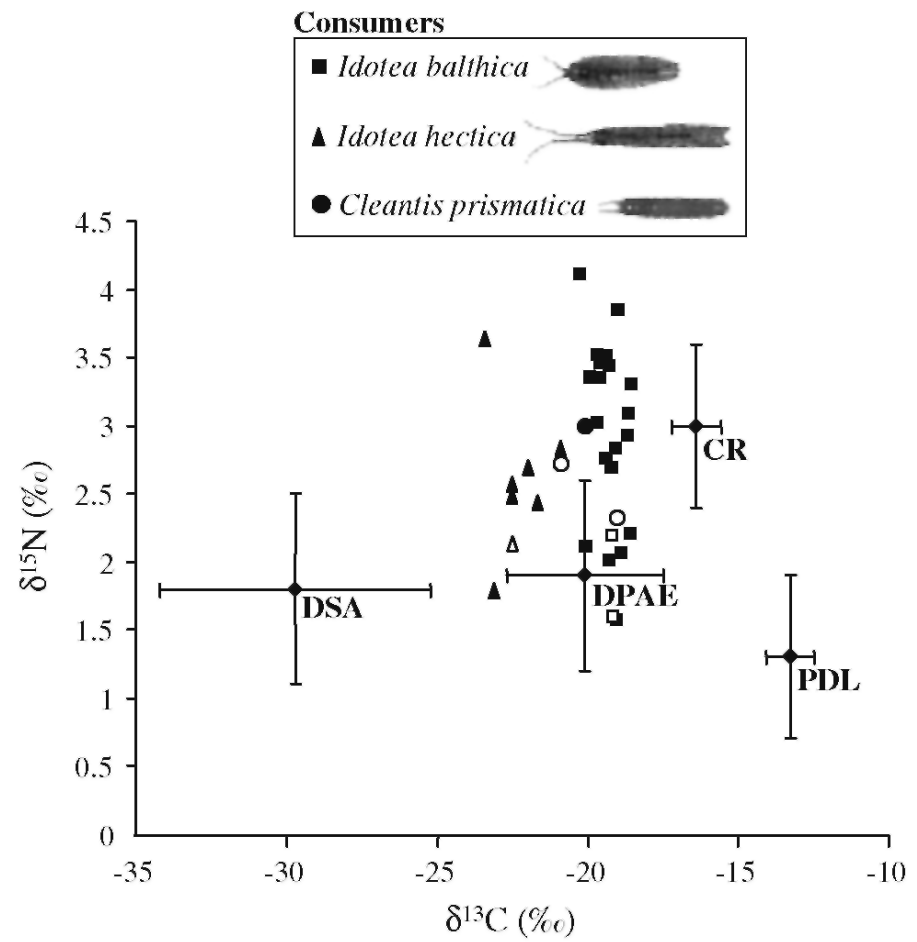


Fig. 3 Correlation between body length and $\delta^{15} N$ values of Idotea balthica. Black and white colours indicate values for individual and pooled specimens, respectively

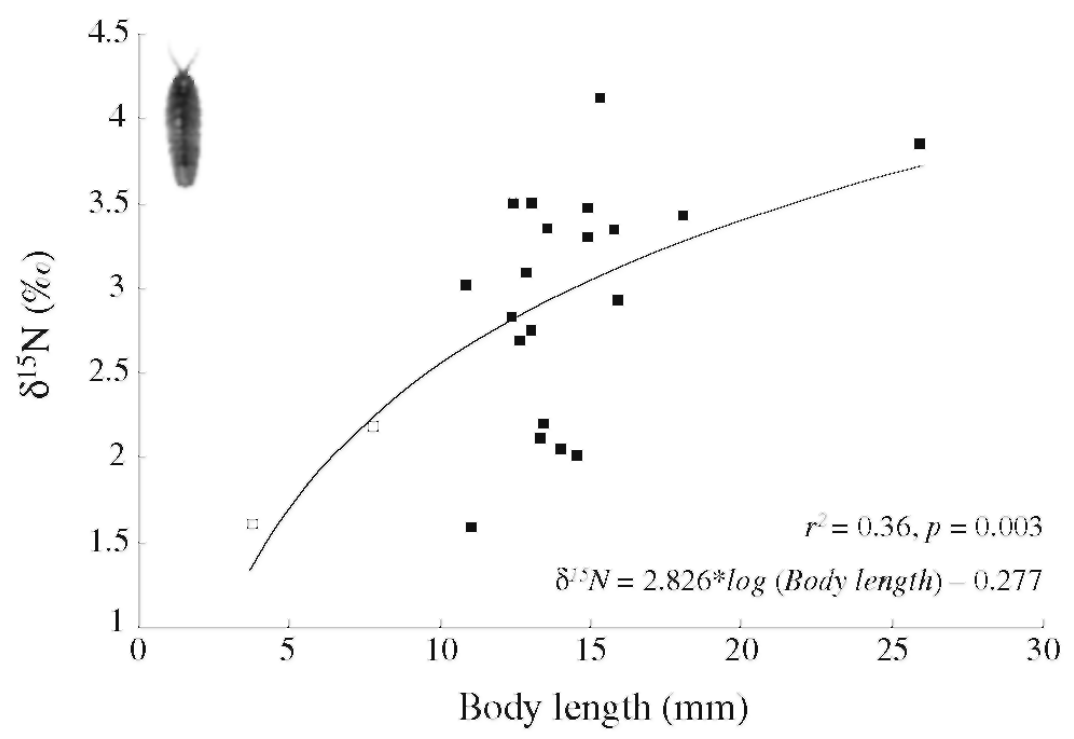

\section{Discussion}

Gut content observations indicate that $P$. oceanica dead leaves are an important part of the ingested food of the three species, although their tissues contain only a small to medium fraction of $P$. oceanica carbon. Furthermore, despite the common food supply (i.e., P. oceanica dead leaves, crustaceans, drift sciaphilous and photophilous algae), we showed that there were considerable inter- and intra-specific differences in diet composition.

\section{Importance of P. oceanica}

The present study shows that the three isopod species ingest considerable quantities of $P$. oceanica dead leaves.

For all the species, dead leaf material was very fragmented and altered. This fragmentation is possible because idoteids possess mouthparts characterized by the presence of large molar processes on each mandible that slide across each other to crush the food and heavily chitinized structures for biting or scraping the food material (Naylor 1955). As previously underlined by Wittmann et al. (1981), these species may play a key role in the degradation process of $P$. oceanica litter.

However, the contribution of $P$. oceanica dead leaves to the diet of idoteids is moderate, representing an average of 20, 18 and $25 \%$ of the assimilated carbon for I. balthica, I. hectica and C. prismatica, respectively. The apparent lack of $P$. oceanica carbon in the diet of idoteids can be explained by the tough consistency of the leaves (even when dead) due to their high fibre content and high amount of poorly digestible structural carbohydrates (mainly lignin and cellulose) (Buia et al. 2000; Klap et al. 2000). In addition, P. oceanica dead leaves are highly encrusted by calcareous epiphytes (Melobesiae) and have high $\mathrm{C} / \mathrm{N}$ ratios, indicating resistance to mechanical factors (fragmentation by animals) and making assimilation more difficult (Pirc and Wollenweber 1988). Thus, the assimilation of $P$. oceanica carbon could only occur in the presence of cellulose and/or lignin digestion. The ability of these species to assimilate such material appears to be affected by the nature and variety of digestive enzymes. The ability to digest cellulose was already demonstrated in some marine isopods (Zimmer et al. 2002). But as for the parent species Idotea wosnesenskii, this ability is weakly developed. Moreover, the use of hepatopancreatic endosymbionts that contribute to cellulose digestion appears absent in marine isopods (Zimmer et al. 2002). 
Fig. 4 Dietary contributions (\%) of the four potential food sources for Idotea balthica, Idotea hectica and Cleantis prismatica. Histograms show the distribution of feasible contributions from each food source to the three isopod species diet resulting from the application of the SIAR isotopic model. Values shown are 5-95\% ranges for these distributions. CR crustaceans, DSA drift sciaphilous algae, DPAE drift photophilous algae and epiphytes of Posidonia oceanica and PDL Posidonia oceanica dead leaves
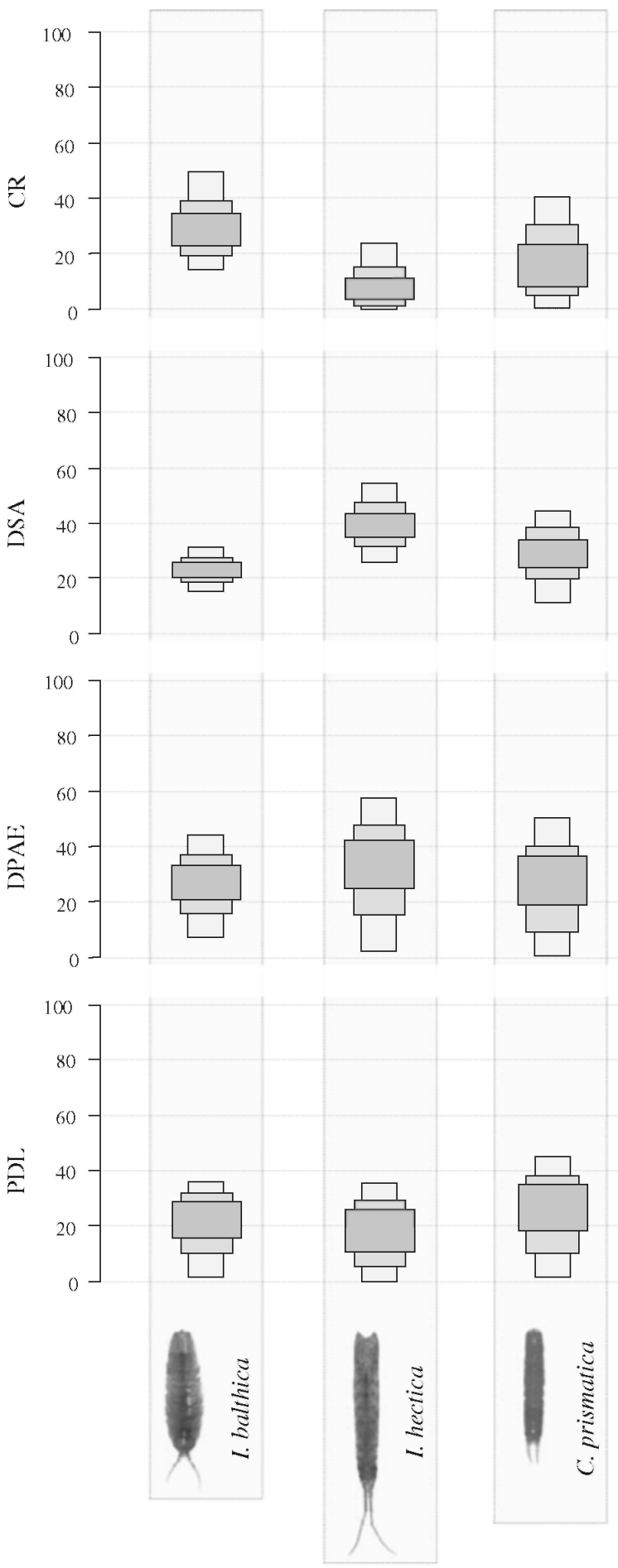

However, some other crustacean detritivores showed evidence of being capable of more efficiently digesting residual plant material (Zimmerman et al. 1979). Lepoint et al. (2006) showed that $P$. oceanica dead leaves could contribute up to $50 \%$ of the total assimilated carbon for the amphipod Gammarus aequicauda, living in the $P$. oceanica litter. Vizzini et al. (2002) also suggested that seagrass material is assimilated by some detritivorous 
amphipods. This assimilation could be mediated through an intestinal symbiosis with bacteria for G. aequicauda (A. Genin, unpublished data) or a production of endogenous cellulases for other aquatic amphipods (McGrath and Matthews 2000; Zimmer and Bartholmé 2003). Overall, we cannot exclude the fact that low digestibility of $P$. oceanica leaf litter, when compared to higher digestibility of algal and animal matter, will result in an increase in relative amount of detrital material in the gut contents, leading to an over-estimation of its nutritive significance.

Two main hypotheses have been proposed to explain why $P$. oceanica dead leaves account for a small to medium fraction of the assimilated carbon, although it is a major component of the gut contents. The first one is that microorganisms (bacteria, fungi, cyanobacteria and diatoms) found at the surface of $P$. oceanica dead leaves constitute the real food source (Mazzella et al. 1992; Lepoint et al. 2006). The $P$. oceanica leaf litter is massively colonized by diatoms, bacteria and marine filamentous fungi (Lepoint et al. 2006), with bacteria reaching densities as high as $4 \times 10^{4}$ cells $\mathrm{mm}^{-2}$ (Velimirov et al. 1981). Microorganisms can provide essential fatty acids, amino acids, sterols, vitamins and other growth factors to detritivores (Phillips 1984). They contain more protein than decaying seagrass fragments with which they are associated (Zimmerman et al. 1979). The work of Fenchel (1970) has indicated that in at least some cases microorganisms constitute the real food source for the detritivores associated to the detritus derived from turtle grass Thalassia testudinum. In the seagrass Syringodium isoetifolium bed, isotopic data suggest that herbivorous heterotrophs depend significantly on epiphytic cyanobacteria (high nitrogen content with $\delta^{13} \mathrm{C}$ of approximately -13,5\%o) rather than seagrass leaves and its detritus (Yamamuro 1999). Holmer et al. (2004) also identified that bacteria $\delta^{13} \mathrm{C}$ ratios in pristine sediments vegetated by the seagrass $P$. oceanica were similar to the seagrass signal or slightly enriched (approximately $13 \%$ o). In our study, we cannot exclude the possibility that microbial biofilm may contribute partially to the isotopic signature of detritus. Undoubtedly, detritivores can receive nourishment by assimilating microorganisms inhabiting seagrass litter (Fenchel 1970), although it is unlikely that they rely solely on microorganisms as an energy source (Blum et al. 1988). The second hypothesis proposes that species benefit from P. oceanica dead leaves to assimilate the brown pigments that they incorporate into their carapace. In Idotea sp., pigments of the cuticle are derived from the food sources of the animals (Lee 1966a, b). Certain parts of the plant material may have different $\delta \mathrm{C}$ than the bulk tissue, which could lead to the variation in $\delta^{13} \mathrm{C}$ in these species (Crawley et al. 2007). The colouration may act as a camouflage against predation. Indeed, Idotea species are subject to severe predation by fish (Wallerstein and Brusca 1982; Vesakoski et al. 2008), and may play a major role in the aquatic food webs, representing a major link among producers and secondary consumers.

Relatively little is known about foraging patterns of these species and underlying mechanisms of food choice and food preference. Laboratory observations of M. Zimmer and K. Lunau (unpublished data) showed that some species of terrestrial isopod respond positively to extracts of microbially inoculated litter but not to extracts of sterilized litter. From this, we could expect that these species search for specific food items such as microbial colonization of the food. However, Jormalainen et al. (2001) suggested that in I. balthica, habitat structure, in terms of predation avoidance, and the spatiotemporal stability of the habitat are more important factors selecting for feeding preferences than the quality of the food.

\section{Inter-specific trophic segregation}

The clear differences in $\delta^{13} \mathrm{C}$ between $P$. oceanica dead leaves and idoteid species which live in $P$. oceanica litter suggest that idoteids do not digest $P$. oceanica dead leaves to any great extent, but rather digest drift photophilous algae, $P$. oceanica leaf epiphytes (both macro and micro epiphytes) and crustaceans, which have a more similar $\delta^{13} \mathrm{C}$ to that of the idoteids. I. balthica and C. prismatica had very close $\delta^{13} \mathrm{C}$ values $(-19.3$ and $20.0 \%$, respectively), suggesting that assimilated matter for these two species is very similar. However, $I$. hectica had a significantly different $\delta^{13} \mathrm{C}$ value (-22.3\%o), reflecting a difference in its diet. A previous study has found a similar $\delta^{13} \mathrm{C}$ for Idotea sp. sampled in the epilithic algal community of the Mediterranean coast (-19.2\%o) and a different $\delta^{13} \mathrm{C}$ for a green individual of Idotea sp. collected in a P. oceanica bed (-15.1\%o) (Lepoint et al. 2000). This last value is very close to the isotopic signature of $P$. oceanica living leaves $(-13.9 \%$ o), suggesting, as observed by Lorenti and Fresi (1983b), that this species is able to nourish itself principally on $P$. oceanica living leaves. However, in our study, $\delta^{13} \mathrm{C}$ for green individuals of $I$. hectica $(-21.4 \pm 0.6 \%$ o) were not distinctly different from brown individuals $(-22.6 \pm 0.6 \%$ ) .

In assessing the contribution of food sources from $P$. oceanica litter, we showed that macroalgae and epiphytes appeared likely to be a substantial contributor for the three isopod species studied. Similar results were also observed by Lepoint et al. (2006) for the amphipods Gammarus aequicauda and Gammarella fucicola, showing that macroalgae and epiphytes contribute up to 50 and $80 \%$ of the total assimilated carbon, respectively. Moreover, the study confirmed that some of these species are omnivores, in particular I. balthica, currently seen 
as one of the main herbivores of many ecosystems (e.g., shallow rocky shores in the Baltic Sea) (Svensson et al. 2004). Fragments of crustaceans were recorded in $46 \%$ of individuals of $I$. balthica in large quantities and contribute up to $31 \%$ of the total assimilated carbon. I. hectica specimens show a tendency towards an herbivorous diet, with algae contributing to $40 \%$ of the assimilated carbon. The idoteid-like valviferan $C$. prismatica has an intermediate diet composed of an equitable mix of the different food sources. The patterns of trophic segregation observed in this study may not be explained by the variety of the structure of the feeding apparatus of these species. Indeed, comparative information between the morphology of Idotea species mouthparts studied by Naylor (1955) and the description of I. hectica by Charfi-Cheikhrouha (2000) did not show major differences.

\section{Intra-specific trophic segregation}

The variation of $\delta^{15} \mathrm{~N}$ values for I. balthica was high (from 1.6 to 4.1\%o) and was explained by differences in body size. This pattern indicates a gradual shift in the diet with increasing size and suggests a trend towards increasing carnivory with maturity. Relationships between body length and stable isotopic signatures have already been found for mysids (Gorokhova and Hansson 1999; Branstrator et al. 2000; Lesutiene et al. 2007), crabs (Dittel et al. 2006) and fish (Renones et al. 2002; Melville and Connolly 2003; Quan et al. 2007). The significant changes in stable isotopic signatures with increasing size are often attributable to ontogenetic diet shifting of animals (Branstrator et al. 2000; Renones et al. 2002; Quan et al. 2007; Lesutiene et al. 2007). In our study, this hypothesis is consistent with gut content analysis, which showed that greater body size admits $I$. balthica to a more diversified diet including macroalgae and crustaceans. However, other studies support that differential metabolic fractionation of nitrogen with age also influences the correlation between body length and $\delta^{15} \mathrm{~N}$ values, especially when there is no correlation between body length and $\delta^{13} \mathrm{C}$ values (Melville and Connolly 2003). Our results showed no correlation between body length and $\delta^{13} \mathrm{C}$ values of $I$. balthica. However, elucidating ${ }^{15} \mathrm{~N}$ accumulation with age and estimating the rate of enrichment due to accumulation require specific laboratory experiments (Gannes et al. 1997; Caut et al. 2009), which are beyond the aim of our study. Thus, caution must be exercised in interpreting the isotopic values. We agree with Melville and Connolly (2003) and Quan et al. (2007) that interpretations of diet based on stable isotope analysis should be limited to individuals of similar size to avoid any potential confounding effects.

This study confirms the importance of combining stable isotope and gut contents information to evaluate the diet of a species. The conjoint analysis allowed us to identify that, while P. oceanica dead leaves were ingested in large quantities, they were assimilated only to a small to moderate extent. Probable reasons for this include the presence of a dense microorganisms population on decaying leaf litter (easy digestible food and richer in nutrients) and the assimilation of brown pigments of the leaf litter by idoteids that they incorporate into their carapace. On the other hand, the good agreement found between gut content and stable isotope data for other food sources allowed us to establish that I. balthica is the more generalist species and is characterized by an omnivorous diet in which crustaceans are the principal component. I. hectica indicated a major contribution of algae material, while $C$. prismatica showed an intermediate diet. The data obtained demonstrated an important trophic diversity, at both intra and inter-specific levels, of the idoteid species living in $P$. oceanica litter. Although these species live in the same biotope, they appear to occupy different microhabitats within the litter and share their food resources. Therefore, habitat heterogeneity and trophic diversity of idoteids are probably the factors that reduce competition and make coexistence possible. As reported by Lepoint et al. (2006), for amphipods, the results also underline the potential role of the isopod species in the degradation of $P$. oceanica litter by mechanically fragmenting the litter and by directly assimilating a fraction of Posidonia carbon. Further investigation of the processes involved in litter breakdown, including the quantification of the role of detritivores and microbial activity, is needed to improve the understanding of $P$. oceanica carbon dynamics and food webs in Mediterranean coastal zones.

\section{Acknowledgments}

The authors would like to thank the staff of the oceanographic research station STARESO (Calvi, Corsica) for valuable help during field work. We would like to thank A. L. Jackson, R. Inger and A. Parnell for their help in the isotopic model, and two anonymous referees for their helpful comments on the manuscript. We wish to thank Jacqueline Minett for improvement of the English. NS receives a doctoral grant from the Belgian Fund for Research for the Industry and Agriculture (FRIA), and GL is a Research Associate at the Belgian National Science Foundation (FRS-FNRS). This study was also funded by the Belgian National Fund for Scientific Research (FRFC 2.45.69.03). This paper is MARE publication number 177. The authors declare that the experiments performed comply with the current laws of France and Belgium. 
Published in : Marine Biology (2010)

Status : Postprint (Author's version)

\section{References}

Arsuffi TL, Suberkropp K (1989) Selective feeding by shredders on leaf-colonizing stream fungi: comparison of macroinvertebrate taxa. Oecologia 79:30-37

Blum LK, Mills AL, Zieman JC, Zieman RT (1988) Abundance of bacteria and fungi in seagrass and mangrove detritus. Mar Ecol Prog Ser 42:73-78

Branstrator DK, Cabana G, Mazumder A, Rasmussen JB (2000) Measuring life-history omnivory in the opossum shrimp, Mysis relicta, with stable nitrogen isotopes. Limnol Oceanogr 45(2):463-467

Buia MC, Gambi MC, Zupo V (2000) Structure and functioning of Mediterranean seagrass ecosystems: an overview. Biol Mar Mediterr 7:167-190

Bunn SE, Loneragan NR, Kempster MA (1995) Effects of acid washing on stable isotope ratios of C and N in penaeid shrimp and seagrass: implications for food-web studies using multiple stable isotopes. Limnol Oceanogr 40(3):622-625

Caut S, Angulo E, Courchamp F (2008) Caution on isotopic model use for analyses of consumer diet. Can J Zool 86:438-445. doi:10.1139/Z08-012

Caut S, Angulo E, Courchamp F (2009) Variation in discrimination factors (Delta N-15 and Delta C-13): the effect of diet isotopic values and applications for diet reconstruction. J Appl Ecol 46(2):443-453. doi:10.1111/j.1365-2664.2009.01620.x

Cebrián J, Duarte CM, Marbà N, Enríquez S, Gallegos M, Olesen B (1996) Herbivory on Posidonia oceanica: magnitude and variability in the Spanish Mediterranean. Mar Ecol Prog Ser 130:147-155

Charfi-Cheikhrouha F (2000) Description of Idotea hectica (Pallas, 1772) from the Tunisian coast (Isopoda, Valvifera). Crustaceana 73:153161

Cox AS (2004) Dynamique et composition faunistique de la litière et des banquettes de Posidonia oceanica en Baie de Calvi. Etude préliminaire. Masterthesis, University of Liège, Belgium, pp 1-38

Crawley KR, Hyndes GA, Vanderklift MA (2007) Variation among diets in discrimination of $\delta^{13} \mathrm{C}$ and $\delta^{15} \mathrm{~N}$ in the amphipod Allorchestes compressa. J Exp Mar Biol Ecol 349:370-377

Dauby P (1989) The stable carbon isotope ratios in benthic food webs of the gulf of Calvi, Corsica. Cont Shelf Res 9:181-195

Dauby P (1995) A $\delta^{13} \mathrm{C}$ study of the feeding habits in four Mediterranean Leptomysis species (Crustacea: Mysidacea). PSZNI Mar Ecol 16:93-102

DeNiro MJ, Epstein S (1981) Isotopic composition of cellulose from aquatic organisms. Geochim Cosmochim Acta 45(10):1885-1894

Dimech M, Borg JA, Schembri PJ (2006) Motile macroinvertebrate assemblages associated with submerged Posidonia oceanica litter accumulations. Biol Mar Medit 13(4):130-133

Dittel AL, Epifanio CE, Fogel ML (2006) Trophic relationships of juvenile blue crabs (Callinectes sapidus) in estuarine habitats. Hydrobiologia 568:379-390. doi:10.1007/s10750-006-0204-2

Fenchel T (1970) Studies on the decomposition of organic detritus derived from the turtle grass Thalassia testudinum. Limnol Oceanogr 15(1): $14-20$

Fenchel T (1977) The significance of bactivorous protozoa in the microbial community of detrital particles. In: Cairns J (ed) Aquatic microbial communities. Garland Pub Co, New York, pp 529-544

Gallmetzer I, Pflugfelder B, Zekely J, Ott JA (2005) Macrofauna diversity in Posidonia oceanica detritus: distribution and diversity of mobile macrofauna in shallow sublittoral accumulations of Posidonia oceanica detritus. Mar Biol 147(2):517-523. doi: 10.1007/s00227-0051594-9

Gannes LZ, OBrien DM, delRio CM (1997) Stable isotopes in animal ecology: assumptions, caveats, and a call for more laboratory experiments. Ecology 78(4):1271-1276

Gorokhova E, Hansson S (1999) An experimental study on variations in stable carbon and nitrogen isotope fractionation during growth of Mysis mixta and Neomysis integer. Can J Fish Aquat Sci 56(11):2203-2210

Graça MAS, Maltby L, Calow P (1993) Importance of fungi in the diet of Gammarus pulex (L.) and Asellus aquaticus (L.). I feeding strategies. Oecologia 93:139-144 
Guarino SM, Gambardella C, Ianniruberto M, de Nicola M (1993) Colour polymorphism in Idotea balthica from the Bay of Naples and its ecological significance. J Mar Biol Assoc UK 64:21-33

Havelange S, Lepoint G, Dauby P, Bouquegneau JM (1997) Feeding of the Sparid fish Sarpa salpa in a seagrass ecosystem: diet and carbon flux. PSZNI Mar Ecol 18:289-297

Holmer M, Duarte CM, Boschker HTS, Barron C (2004) Carbon cycling and bacterial carbon sources in pristine and impacted Mediterranean seagrass sediments. Aquat Microb Ecol 36:227-237

Jackson AL, Inger R, Bearhop S, Parnell A (2009) Erroneous behaviour of MixSIR, a recently published Bayesian isotope mixing model: a discussion of Moore \& Semmens (2008). Ecol Lett 12(3):E1-E5. doi:10.1111/j.1461-0248.2008.01233.x

Janssens M (2000) Etude in situ de la production primaire des macroalgues d'une baie méditerranéenne et influences dans le cycle du carbone. Ph.D. thesis, University of Liège, Belgium, pp 1-270

Jennings S, Renones O, Morales Nin B, Polunin NVC, Moranta J, Coll J (1997) Spatial variation in the N-15 and C-13 stable isotope composition of plants, invertebrates and fishes on Mediterranean reefs: Implications for the study of trophic pathways. Mar Ecol Prog Ser 146:109-116

Jormalainen V, Honkanen T, Heikkila N (2001) Feeding preferences and performance of a marine isopod on seaweed hosts: cost of habitat specialization. Mar Ecol Prog Ser 220:219-230

Klap VA, Hemminga MA, Boon JJ (2000) Retention of lignin in seagrasses: angiosperms that returned to the sea. Mar Ecol Prog Ser 194:111

Lee WL (1966a) Color change and the ecology of the marine isopod Idothea (Pentidotea) montereyensis Maloney, 1933. Ecology 47:930941

Lee WL (1966b) Pigmentation of the marine Isopod Idotea montereyensis. Comp Biochem Phys 18:17-36

Lepoint G, Nyssen F, Gobert S, Dauby P, Bouquegneau JM (2000) Relative impact of a seagrass bed and its adjacent epilithic algal community in consumer diets. Mar Biol 136(3):513-518

Lepoint G, Cox AS, Dauby P, Poulicek M, Gobert S (2006) Food sources of two detritivore amphipods associated with the seagrass Posidonia oceanica leaf litter. Mar Biol Res 2(5):355-365. doi: 10.1080/17451000600962797

Lesutiene J, Gorokhova E, Gasiunaite ZR, Razinkovas A (2007) Isotopic evidence for zooplankton as an important food source for the mysid Paramysis lacustris in the Curonian Lagoon, the south-eastern Baltic Sea. Estuar Coast Shelf Sci 73:73-80. doi: 10.1016/j.ecss.2006.12.010

Lorenti M, Fresi E (1983a) Vertical zonation of vagile fauna from the foliar stratum of a Posidonia oceanica bed. Isopoda. Rapp Comm int Mer Medit 28(3): 143-145

Lorenti M, Fresi E (1983b) Grazing of Idotea baltica on Posidonia oceanica: preliminary observations. Rapp Comm Int Mer Medit 28(3): $147-148$

Mateo MA, Romero J (1997) Detritus dynamics in the seagrass Posidonia oceanica: elements for an ecosystem carbon and nutrient budget. Mar Ecol Prog Ser 151:43-53

Mateo MA, Cebrián J, Dunton K, Mutchler T (2006) Carbon flux in seagrass ecosystems. In: Larkum AWD, Orth JJ, Duarte CM (eds) Seagrasses: biology, ecology and conservation. Springer, New York, pp 159-192

Mazzella L, Buia MC, Gambi MC, Lorenti M, Russo GF, Scipione MB, Zupo V (1992) Plant-animal trophic relationships in the Posidonia oceanica ecosystem of the Mediterranean Sea: a review. In: John DM, Hawkins SJ, Price JH (eds) Plant-animal interactions in the marine benthos. The systematics association, vol 46. Clarendon Press, Oxford, pp 165-187

McGrath CC, Matthews RA (2000) Cellulase activity in the freshwater amphipod Gammarus lacustris. J N Am Benthol Soc 19:298-307

Melville AJ, Connolly RM (2003) Spatial analysis of stable isotope data to determine primary sources of nutrition for fish. Oecologia 136:499-507. doi:10.1007/s00442-003-1302-8

Moore JW, Semmens BX (2008) Incorporating uncertainty and prior information into stable isotope mixing models. Biol Lett 11:470-480. doi:10.1111/j.1461-0248.2008.01163.x

Naylor E (1955) The diet and feeding mechanism of Idotea. J Mar Biol Assoc UK 34:347-355

Nicotri ME (1980) Factors involved in herbivore food preference. J Exp Mar Biol Ecol 42:13-26

Pasqualini V (1997) Caractérisation des peuplements et types de fonds le long du littoral corse (Méditerranée, France). Ph.D. thesis, Univ Corse, France, pp 1-165 
Published in : Marine Biology (2010)

Status : Postprint (Author's version)

Pergent G, Romero J, Pergent-Martini C, Mateo MA, Boudouresque CF (1994) Primary production stocks and fluxes in the Mediterranean seagrass Posidonia oceanica. Mar Ecol Prog Ser 106:139-146

Peterson BJ, Fry B (1987) Stable isotopes in ecosystem studies. Ann Rev Ecol Syst 18:293-320

Phillips NW (1984) Role of different microbes and substrates as potential suppliers of specific, essential nutrients to marine detritivores. Bull Mar Sci 35:283-298

Pirc H, Wollenweber B (1988) Seasonal changes in nitrogen, free amino acids, and C/N ratios in Mediterranean seagrasses. Mar Ecol 9(2): $167-179$

Poore GCB, Lew Ton HM (1990) The Holognathidae (Crustacea: Isopoda: Valvifera) expanded and redefined on the basis of body-plan. Invertebr Taxon 4:55-80

Prado P, Tomas F, Alcoverro T, Romero J (2007) Extensive direct measurements of Posidonia oceanica defoliation confirm the importance of herbivory in temperate seagrass meadows. Mar Ecol Prog Ser 340:63-71

Quan WM, Fu CZ, Jin BS, Luo YQ, Li B, Chen JK, Wu JH (2007) Tidal marshes as energy sources for commercially important nektonic organisms: stable isotope analysis. Mar Ecol Prog Ser 352:89-99. doi:10.3354/meps07160

Reñones O, Polunin VC, Goni R (2002) Size related dietary shifts of Epinephelus marginatus in a western Mediterranean littoral ecosystem: an isotope and stomach content analysis. J Fish Biol 61:122-137

Salemaa H (1978) Geographic variability in the colour polymorphism of Idotea balthica (Isopoda) in the northern Baltic. Hereditas 88:165182

Salemaa H (1979) Ecology of Idotea spp. (Isopoda) in the northern Baltic. Ophelia 18:133-150

Svensson PA, Malm T, Engkvist R (2004) Distribution and host plant preference of Idotea baltica (Pallas) (Crustacea: Isopoda) on shallow rocky shores in the central Baltica Sea. Sarsia 89:1-7

Tinturier-Hamelin E (1963) Polychromatisme et determination génétique du sexe chez l'espèce polytypique Idotea balthica (Pallas) (Isopode Valvifère). Cah Biol Mar 4:473-591

Vanderklift MA, Ponsard S (2003) Sources of variation in consumerdiet $\delta^{15} \mathrm{~N}$ enrichment: a meta-analysis. Oecologia 136:169-182. doi:10.1007/S00442-003- 1270-Z

Vela A (2006) Fonctionnement et production primaire des herbiers à Posidonia oceanica (L.) Delile en Méditerranée. Ph.D. thesis, University of Corsica, France, pp 1-126

Velimirov B, Ott JA, Novak R (1981) Microorganisms on macrophyte debris: biodegradation and its implication in the food web. Kieler Meeresf Sonderh 5:333-344

Vesakoski O, Merilaita S, Jormalainen V (2008) Reckless males, rational females: dynamic trade-off between food and shelter in the marine isopod Idotea balthica. Behav Process 79:175-181

Vizzini S, Sara G, Michener RH, Mazzola A (2002) The role and contribution of the seagrass Posidonia oceanica (L.) Delile organic matter for secondary consumers as revealed by carbon and nitrogen stable isotope analysis. Acta Oecol 23:277-285

Wallerstein BR, Brusca RC (1982) Fish predation: a preliminary study of its role in the zoogeography and evolution of shallow-water idoteid isopods (Crustacea: Isopoda: Idoteidae). J Bioge-ogr 9:135-150

Wittmann K, Scipione MB, Fresi E (1981) Some laboratory experiments on the activity of the macrofauna in the fragmentation of detrital leaves of Posidonia oceanica (L.) Delile. Rapp Comm int Mer Medit 27(2):205-206

Yamamuro M (1999) Importance of epiphytic cyanobacteria as food sources for heterotrophs in a tropical seagrass bed. Coral Reefs 18(3):263-271

Zimmer M, Bartholmé S (2003) Bacterial endosymbionts in Asellus aquaticus (Isopoda) and Gammarus pulex (Amphipoda) and their contribution to digestion. Limnol Oceanogr 48:2208-2213

Zimmer M, Danko JP, Pennings SC, Danford AR, Carefoot TH, Ziegler A, Uglow RF (2002) Cellulose digestion and phenol oxidation in coastal isopods (Crustacea: Isopoda). Mar Biol 140:1207-1213. doi:10.1007/s00227-002-0800-2

Zimmerman R, Gibson R, Harrington J (1979) Herbivory and detritivory among gammaridean amphipods from a Florida seagrass community. Mar Biol 54:41-47 